\title{
СЕ ЋАњА
}

UDC 925.52

Dr Željko Fajfrić

advokat u Sidu

\section{ADVOKATSKA PORODICA KAMBER*}

Porodica Kamber je poreklom iz Rume (cincarskog su ili polucincarskog porekla), a prvi njeni pomeni idu u drugu polovinu XVIII veka. Po svemu sudeći prvi njen poznati predak bio je Petar Kamber (spominje se u Protokolu iz 1831. godine) koji je imao sinove Đorđa, Jovana, Andriju (bio lekar) i Dimitrija i ćerku Eufemiju.

Najstariji sin Đorđe bio je oženjen sa Eudoksijom (rođena Karamat) ostaje u Rumi, Dimitrije se seli u Sremske Karlovce i tamo živi (1810), a onda se opet spominje u Rumi 1815. godine (kao Rumensis incola). Eufemija se udala za Cincara Relju Anastasijevića (1815).

Za ovu priču bitna su ostala braća - Jovan i Andrija.

\section{Advokat Jovan Kamber (otac)}

Rođen je 1773. godine. Prava je završio 1798. godine, a diplomu je dobio 18. februara 1799. godine i publikovao ju je 22. aprila.

Bio je silovit čovek i o njegovim ispadima ima dosta priča. Tako se 1802. godine potukao sa Auksentijem Markovićem. U kafanu „Zeleni venac" došao je Kamber tražeći vlasnika senatora Pauza. Upravo tada tu je sedelo društvo (Dimitrije Stanisavljević, Jovan Milanković, Auksentije Marković, Toma Bogdanović, Jovan Jovanović Kiš, Aleksa Carnojević (stražmeštar policije). Stanisavljević pozove Kambera u društvo i ovaj to prihvati. Tokom razgovora započne Auksentije Marković da zamera Kamberu što pomaže senatora Ostojića u parnici protiv njega (Auksentija). Na kraju je, verovatno pripiti Auksentije, počeo Kamberu da osporava advokatsko znanje preteći mu kaznom Silentii. Reč po reč i započnu oni jedan

* Rad primljen: 01. 09. 2009. godine. 
drugome da viču „lažeš”. Onda je započela tuča u kojoj je Kamber dobio dva udarca štapom po glavi, a sam je pogodio štapom jednom. Kada im je društvo pootimalo štapove oni se dohvate za kose. Čini se da je Kamber bio slabiji jer je vikao i pozivao u pomoć prisutne: „Je li pravo da kod vas tolikih život izgubim". Kada ga je društvo konačno oslobodilo Kamber je napustio kafanu, ali je napolju sačekao Auksentija i onda ga gađao kamenjem.

Kamber je ostao upamćen i po jednoj čudnoj parnici. Godine 1804. on je primio parnicu koja je trajala već 25 godina, dakle započela je pre negoli se on i rodio. U toj parnici tužila se za neku kuću udovica Ana (iza pokojnog muža Jovana Nikolića). Kamber je nakon 6 godina parnicu dobio i uveo Anu u kuću. Onda joj je izradio zajam kod Narodnih fondova i sa sumom od 35.000 forinti ona je uredila kuću tako da je od 1824 . godine dobijala za nju preko 3000 forinti godišnje kirije. Kamberu je obećan, između ostalog, i udoban stan u kući ukoliko parnicu dobije.

On je parnicu zaista i dobio, ali ne samo da nije dobio stan nego ni najobičniji advokatski honorar nije uspeo da naplati. Kasnije će Ana da imenuje protu Danila za izvršioca testamenta. Godine 1822. Kamber će od prote da traži isplatu svoga honorara. Kada je to prota odbio Kamber ga je napao optužbama da on (prota) zeva na tuđa imanja, da je lovac na bapske testamente i da je, dok je Ana umirala, preturao po njenim kovčezima tražeći adiđare i novac. Na kraju je Kamber ipak uspeo da dobije 1000 forinti.

Od 1807. godine on je vicefiškal Sremske županije, 1808. godine postaje fiškal spahiluka Turski Bečej, a od 23. septembra 1816. godine postaje gradski fiškal u Novom Sadu. Od 1813. godine on je senator. Kao takav (senator) biće duži niz godina gradski kapetan. Oženio se ćerkom Jakova Bogdanovića koja se zvala Julijana. Sa njome će imati sedmoro dece. Tokom 1828. godine bio je čak i suspendovan (zbog nasilja) kako od službe tako i od plate. Ipak, vratio se u senatorsku i kapetansku službu. Tu je nastavio po starom.

Kamber je 1825. godine tražio da dobije plemstvo, ali neće uspeti. Zbog toga će dosta kasnije (1832. godine) Jovan Kamber da dođe u sukob sa advokatom Endredijem, ovaj je neoprezno počeo da ismejava Jovana nazivajući ga seljačkim sinom, a onda je iz toga potekla cela diskusija.

Jovan Kamber počinje da navodi da je porodica Kamber toliko stara da je o njoj pevao još grčki Homer i da u Ilijadi spominje kako je daleki predak Kambera krenuo u rat sa Trojom vodeći devet brodova. Nadalje, da je neki Kamber 1550. godine bio hrabri vojskovođa i da to potvrđuje Ištvanfi. Takođe da mađarski istoričar Konji navodi tog istog Kambera pri opsadi Sigeta, odnosno da je taj Kamber tada išao na megdane sa Turcima koji su opsedali Siget. I na to sve, Jovan Kamber nadodaje da je francuski istoričar Difren govorio kako i sam legendarni Skenderbeg potiče od Kambera. Nadalje, da je porodica Kamber jedna od prvih koje su naselile Rumu, stekla je mnoge zasluge u ratovima protiv Turaka, pa čak 
da je i on sam (Jovan) služio u vojsci i ,vratio se samo sa grančicom mira, radi čega je i postao asesor sudske table".

Budući da ga je advokat Endredi pokušao potceniti time da je Grk vulgo Cincar, Jovan Kamber odgovara da se on samo "diči ako pripada narodu Miltijada, Temistokla, Alkibijada i Aristida”. I sam naziv Cincar, Kamber objašnjava: etimologija reči je rumunska, sastoji se iz dve reči: cin i car, što kod Rumuna znači pepeo (odnosno - zemlju) i cara. To nadalje znači da Cincar znači da je neko ugledan vlastelin (gospodar zemlje).

Tokom 1834. godine doći će u sukob sa profesorom Petrom Jovanovićem (koji je ujedno bio i advokat). U toj svađi Kamber će vrlo ljutito, uz mnogo mržnje i preziranja, da Jovanovića nazove Faetonom i da mu prebacuje kako priprema propast celom gradu. Upravo zahvaljujući Kamberu biće Jovanović kažnjen kaznom advokatskog ćutanja, a istovremeno će mu se oduzeti i profesura. Tu će Kamber da napravi aluziju i na Jovanovićev (Mačak) nadimak govoreći: ,misli Mačak da sam ja njegov miš”.

Onda je napravio novu uvredu. Dana 8. marta 1837. godine uvredio je počasnog vicefiskala Grigorija Jovšića (tada delovođa izabranog obštestva) time što je njega (Grigorija) i celo obštestvo nazvao - bankrotima.

Do 1848. godine bio je gradski načelnik, a posle revolucije ostaje bez službe. Ipak, dobijao je penziju od 500 forinti. Nedugo potom, 1. oktobra (19. septembra) 1848. godine, kada bude imao 75 godina, poginuće u svom vinogradu. Tu pogibiju opisuje Mihailo Polit. Kako navodi Jovan Kamber je otišao „u svoj vinograd blizu Bukovca. Tu dođu neki naoružani Bukovčani, da ga kao novosadskog Mađarona vizitiraju, ali on, kako je bio ponosit, naprasit i odvažan, potegne za svojom puškom, našto Bukovčani opale na njega, te ga ubiju. Kambera donesu mrtvoga u Novi Sad i tu ga sahrane u porodičnu kosturnicu baš pred glavni ulaz Nikolajevske crkve."

Rečeno je da je sa ženom Julijanom Bogdanović imao sedmoro dece. Stefan je rođen 1815. godine, umro je 1849. godine (pretpostavlja se u bežaniji, možda u Zemunu). Drugi sin Jakov učio je školu u Novom Sadu (gimnaziju), tu je ostao zapis da je bio „obestan i stalno činio izgrede u školi i crkvi". To je bio razlog zbog čega školu nije završio u Novom Sadu.

U momentu kada je Jovan Kamber umro, u životu mu je petoro dece: ćerka Sofija (udana Pasković), ćerka Jelisaveta (udana Štam u Beču), ćerka Marija (udana za Danila Medakovića), i dva sina Pavle i Đorđe, obojica advokati.

\section{Advokat Pavle Kamber (sin)}

Diplomirao je 1838. godine. Po svemu sudeći advokaturom se malo bavio. Tokom 1869. godine razboleo se tako da njegova sestra Sofija Pasković javlja gradskom sudu da joj se brat „od dužeg vremena u takvom 
stanju nalazi, da on zbog svoje nerasudnosti nije u stanju svojim imanjem upravljati". Uz ovo pismo dostavljeno je i lekarsko uverenje iz kojeg se vidi da je Pavle Kamber zbog srčanog udara „u poslednje vreme telesno, a još više duševno tako klonuo, da se nerasudnim kvalifikovati mora. Iz čega sledi, da on niti za upravu samog sebe niti pak svog imanja sposoban nije".

On je tada umno poremećen i to baš sestra Sofija navodi tražeći da se za staraoca (kuratora) postavi brat mu Đorđe. Tako će i biti, od 10. aprila 1869. godine njemu je postavljen staralac. Nakon toga odveden je u Budim na lečenje gde će umreti (verovatno u bolnici za umno poremećene) 29. februara 1870 . godine. Nije imao dece.

\section{Advokat Đorđe Kamber (sin)}

Đorđe Kamber, sin Jovanov, je slično poput svoga brata Pavla sveukupno malo vremena proveo u advokaturi. Od 1832. do 1838. godine završiće šest razreda gimnazije (kao jedan od najboljih) u Novom Sadu, a prava u Pešti. Tokom 1847. godine on je svršeni jurat pa se nudi Magistratu da bude pisar. Dana 27. marta 1848. godine dobija advokatsku diplomu (sa ocenom „pohvalan”) pa je 12. maja publikuje. No, advokaturom se ne bavi jer ga je u tome sprečila Buna 1848. godine.

Baš iz toga vremena postoji nekoliko stranica kod Jakova Ignjatovića (Memoari) gde on priča o Đorđu Kamberu. Njih dvojica su se poznavali još iz Pešte, a Ignjatović ga jako hvali: „spomenuću jedan fakt što jako karakteriše duh, kolegijalnost i solidarnost đačku". Onda Ignjatović priča kako je on (Ignjatović) tada bio na filozofskoj klasi, a Kamber je učio ,,indžinirski kurs”, tada je policija pritvorila nekoga đaka. To je bio skandal: „Đaka policija da zatvori! To nije šala, jer đaku u nikakvom smislu i obziru nije bio gospodar ni sudija ni policaj, već univerzitetski akademički senat, gde opet, naravno, za kakav izgred morao je biti iz škole isteran ili bi dobio 'consilium abeundi', gde za takav običan izgred kod policije sa jednim danom do vremena istrežnjenja sve bi mirno obavio".

To je među đacima izazvalo pobunu i svi oni u gomili kreću „na policiju da izbave kolegu”. Na čelu je bio baš Đorđe (Đoka) Kamber: „Tu sa njim, u gomili, mali i veliki, slabi i jaki. Đoka Kamber, predvoditelj, krasan pernat mladić, sa kuždravom, nakuždravljenom kosom, abdelkadersko lice, crne oči mu sevaju, na njemu fini, zejtinaste boje 'krišpin', kuražno napred stupa, s njime nekoliko od prvaka uprave grede u policajni ured, mi ostali ostragu čekamo šta će biti."

Sada dolaze zaista uzbudljivi redovi koji jasno govore kakav je Đorđe Kamber u zbilji bio: „Kamber parlamentira sa vice kapetanom. Kamber kreše, a kapetan popušta, poznaje mu se po kapitulirajućem glasu, priznaje đačku neprikosnovenost, i sužnika sasvim zdravog i trezvenog otpusti. Kamber kao trijumfator okrene se, udalji se, a gomila koje za njim 
koje raspudi se, koji ode na čašu piva, ako mu je stigao novac ili ima kredita, koji, pak, u tom nedostatku reflektuju o toj đačkoj kampanji i malo uveličano je dalje rasprostiru".

Dana 24. januara Đorđe Kamber 1854. godine polaže ponovo advokatsku zakletvu. U to vreme on uživa veoma veliki ugled u Novom Sadu: „Kamber je bio i u Novom Sadu popularan, kao sin čuvenog magistratlije i veleposednika, starog Kambera, a i kao inače korektan karakter" (Jakov Ignjatović).

Ipak, advokatura ga ne zanima pa se uglavnom bavi na salašu svoje majke, naslednice Bogdanovića. Za nju se navodi da je: „od znamenite porodice Bogdan koja je o svom trošku Nikolajevsku crkvu u N. Sadu nazidala i dugo o svom trošku sveštenika izdržavala". Kako se navodi: „za vreme Bahove sisteme Đorđe se sasvim povukao na svoj nasleđeni salaš gde je sve ugodnosti za gostoprimstvo imao, i gde mu je svaki prijatelj i poznanik dobro došao". Ipak, tokom 1861. godine prihvata se dužnosti gradskog kapetana u Magistratu. No, ne za dugo, deset meseci kasnije on odstupa, razlog je bio u tome što je vlast odlučila da (neustavno) ukloni Svetozara Miletića iz gradskog načelstva.

Odlazi na svoj salaš i tamo će biti i krajem januara 1864. godine, tada je upražnjeno mesto gradskog kapetana, kada mu dođe gradska deputacija da mu nudi mesto gradskog kapetana. Tek krajem maja 1867. on se opet prihvata te službe. Tada je Svetozar Miletić ponovo izabran za gradskog načelnika. Kasnije će oko te službe izbiti novi problemi, pa će Kamber opet odstupiti, pa onda opet u aprilu 1869. godine prihvatiti tu službu. To će biti sve do 26. marta 1879. godine kada „zbog slabog zdravlja i preinačeni porodični okolnosti zahvaljuje na svojoj službi”.

Od 1875. godine on je predsednik Katastralnog suda u Novom Sadu, a onda 1881. godine opet dolazi na funkciju kapetana, a 1884. godine odstupa i povlači se. U to vreme on je već uveliko istupao protiv Svetozara Miletića (svoga nekadašnjeg saveznika) pa ga je Jova Jovanović Zmaj kvalifikovao kao „odmetnika”. Dao mu je (1881. godine) ove stihove:

\author{
„Dobro došli Salašani \\ Na izboru svi ste skupa, \\ Svi poštena vedra lica, \\ Salašani, Salašani, \\ A kamo vam perjanica? \\ Svi stojite vedra čela, \\ Svi stojite bistra oka, \\ A kamo vam perjanica \\ - Perjanica Kamber Đoka? \\ Odvrže se vaša dika, \\ Eno tuđom stazom hodi - \\ Eno tudim glasom zbori, - \\ Eno tuđe kolo vodi! \\ Kida veze, cepa uze,
}


Čupa spomen mladih dana, -

Oj, pod starost šta dočeka,

Perjanico Salašana!

Suzno gledam starog Đoku

Al očima ne verujem

Bog ubio ta vremena

U kim ljudi dušu gube,

Celu prošlost svoju zgaze,

Svoje prezru, tude ljube.

Umro je 17 (5) maja 1891. godine. Nije imao dece tako da je to bilo izumiranje porodice Kamber. 